\begin{tabular}{lccc} 
VERSITA & GOSPODARKA & SUROWCAMI & MINERALNYMI \\
\hline \multirow{2}{*}{ Tom 29} & 2013 & Zeszyt 4 \\
& & DOI 10.2478/gospo-2013-0047 &
\end{tabular}

\title{
Studies of mercury content in selected coal seams of the Upper Silesian Coal Basin
}

\begin{abstract}
Introduction
The presence of mercury in coal is well known. Mercury is a natural contaminating element present in coal and in other fossil fuels. The concentration of mercury in coal may vary, and its content in black coal is generally lower than in lignite (e.g. Bojakowska, Sokołowska 2001; Chmielniak et al. 2012). Mercury occurs in coal in several forms, probably mainly as divalent mercury. Most mercury compounds in coal (60-70\%) occur in combination with sulphur as additives to $\mathrm{FeS}_{2}$ pyrite and as $\mathrm{HgS}$ mercury sulphide. Some of it can also be bound to coal maceral. Mercury as a component of the organic fraction of carbon constitutes the remaining 30-40\% (e.g. Bojakowska, Sokołowska 2001; Głodek, Pacyna 2007).

The fuel and energy industry is one of the main anthropogenic sources of mercury emissions into the environment (e.g. Bojakowska, Sokołowska 2001; Lorenz 2005; Klojzy-Karczmarczyk, Mazurek 2007; Olkuski 2007; Smoliński 2007; Klojzy-Karczmarczyk, Mazurek 2008; Lorenz, Grudziński 2008; Leśniewska et al. 2009; Chmielniak et al. 2012; Wichliński et al. 2012). The structure of fuel consumption has changed very little in recent years, and the dominant fuels in the Polish power industry are still coal and lignite, which is now an essential element of national energy security (Mokrzycki, Uliasz-Boczeńczyk 2009; Gawłowski et al. 2010). The share of coal in electricity production between 1993 and 2011 ranged from 97 to 86\% (Blaschke 2005; Barchański 2010; Grudziński 2013). Polish coal is also exported to other European countries (Olkuski, Stala-Szlugaj 2012).
\end{abstract}

* Ph.D. Eng, ** M.Sc. Eng., Mineral and Energy Economy Research Institute of the Polish Academy of Sciences, Kraków, Poland; e-mail: beatakk@min-pan.krakow.pl; jan@min-pan.krakow.pl 
In Poland, no regular studies have been conducted to investigate the total mercury content in coal, and the available data indicate a significant divergence in the obtained results. A comparison of the results presented in past documentation shows that in the existing coal mines in Poland, the average mercury content in coal ranged from 0.06 to $0.15 \mathrm{mg} / \mathrm{kg}$, although content which significantly differs from the average has also been reported (Bojakowska, Sokołowska 2001; Bojarska 2006; Wojnar, Wisz 2006; Smoliński 2007; Chmielniak et al. 2012; Okońska et al. 2013). Mercury content in coal deposits around the world also varies significantly. The content of this element in coal samples from different deposits generally ranges from 0.03 to $0.3 \mathrm{mg} / \mathrm{kg}$. Test results of coal samples from the United States indicate mercury content ranging from 0.03 to $0.20 \mathrm{mg} / \mathrm{kg}$, from Russia between 0.07 and $0.12 \mathrm{mg} / \mathrm{kg}$, from China between 0.06 and $0.08 \mathrm{mg} / \mathrm{kg}$, from Australia between 0.05 and $0.1 \mathrm{mg} / \mathrm{kg}$, and from the U.K. of $0.11 \mathrm{mg} / \mathrm{kg}$ (http://ec.europa.eu/, 2004; Olkuski 2007; Smoliński 2007).

The aim of the research presented in this paper was to determine the mercury content in coal seams of the Upper Silesian Coal Basin (USCB), and to present the test results in the context of prior studies. The various Polish coal deposit samples analysed were mined in 2011 and provided by mining operators.

\section{Analysed research area}

The area subjected to the mercury content study included selected coal seams of the Upper Silesian Coal Basin (USCB), which is the main Polish coal basin. The mined areas

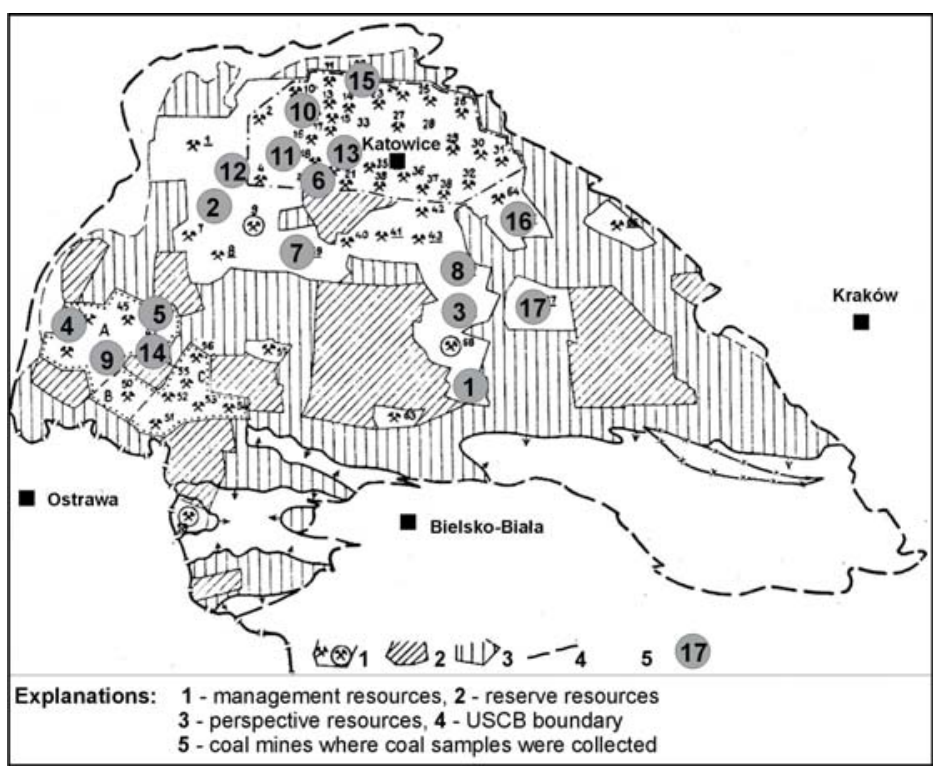

Fig. 1. Location of coal mines in USCB where coal samples were collected (Kotas 1987)

Rys. 1. Lokalizacja rejonów eksploatacji węgli kamiennych na obszarze GZW w których pobrano próbki węgli (Kotas 1987) 
corresponding to individual mines where coal samples were collected are shown in Figure 1 and Table 1.

Existing coal resources in the Upper Silesian Coal Basin have been documented in 128 deposits, including 36 which have been abandoned (as of 31 Dec. 2012). In 2012, coal mining in Poland was estimated at 71.3 million tons, of which 64.7 million tons were from the Upper Silesian Coal Basin (Szuflicki et al., edited, 2013).

In the present study, the USCB area was divided into three parts - the western, central, and eastern. A schematic cross-section through the region is shown in Figure 2 (Kotas 1987).

TABLE 1

The averaged results of mercury content measurements in available coal samples from individual mined seams in the Upper Silesian Coal Basin - own research of authors

TABELA 1

Uśrednione wyniki pomiarów zawartości rtęci w udostępnionych próbkach węgli z poszczególnych rejonów eksploatacji GZW - badania własne autorów

\begin{tabular}{|c|c|c|c|}
\hline $\begin{array}{l}\text { No. of mining } \\
\text { region (mine) } \\
\text { in Fig. } 1\end{array}$ & Mined seams in region & Lithostratigraphic members & $\begin{array}{c}\text { Average } \mathrm{Hg} \text { total } \\
\text { content }[\mathrm{mg} / \mathrm{kg}] \\
\text { (in the air-dry state) }\end{array}$ \\
\hline 1. & $352,364,401,510$ & Orzesze, Ruda, Siodło horizons & 0.0496 \\
\hline 2. & $401,407,408,501$ & Ruda, Siodło horizons & 0.1361 \\
\hline 3. & $205,206,209$ & Łaziska horizon & 0.1589 \\
\hline 4. & $703,707,713$ & Jaklowiec horizon & 0.0589 \\
\hline 5. & 404,405 & Ruda horizon & 0.0598 \\
\hline 6. & $402,405,411,416,418,502,504$ & Ruda, Siodło horizon & 0.0633 \\
\hline 7. & 324,325 & Orzesze horizon & 0.1527 \\
\hline 8. & $206,207,209,308$ & Łaziska, Orzesze horizons & 0.0571 \\
\hline 9. & $503,504,505,707,712$ & Siodło, Jaklowiec horizons & 0.0717 \\
\hline 10. & $503,504,510,615$ & Siodło, Poręba horizons & 0.0331 \\
\hline 11. & $408,504,506,507$ & Ruda, Siodło horizons & 0.0910 \\
\hline 12. & 405,408 & Ruda horizon & 0.0926 \\
\hline 13. & 416,504 & Ruda, Siodło horizons & 0.0856 \\
\hline 14. & $408,410,501,502$ & Ruda, Siodło horizons & 0.1238 \\
\hline 15. & $501,506,510$ & Siodło horizon & 0.1144 \\
\hline 16. & $118,119,203,207$ & Libiąż horizon & 0.0585 \\
\hline 17. & $207,209,304$ & Łaziska, Orzesze horizons & 0.0416 \\
\hline
\end{tabular}

Moisture samples in air-dry state: generally $1.3-4.7 \%$. 


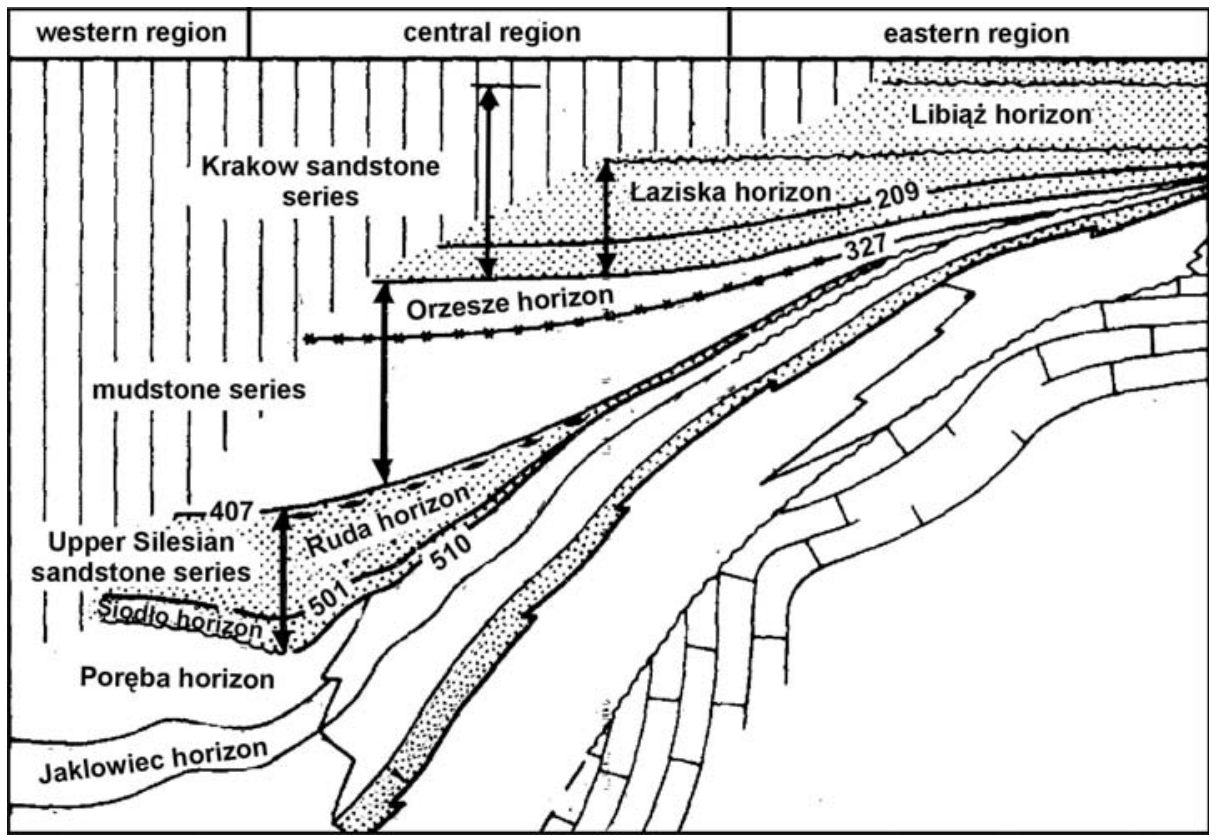

Fig. 2. Schematic cross-section of the productive Carboniferous horizon in USCB (Kotas 1987)

Rys. 2. Schematyczny przekrój przez utwory karbonu produktywnego GZW (Kotas 1987)

In the Upper Carboniferous productive series, sediments were distinguished which differed in lithological and facies formation and in the thickness of the seams and resources. The mined coal seams were mainly located in the members of the Krakow sandstone series, the mudstone series, and the Upper Silesian sandstone series (Fig. 2). Within these series, a number of horizons may be distinguished where coal seams are mined. The Libiaż (group 100) and Laziska (group 200) horizons are the shallowest. Deeper horizons include Orzesze (group 300) and Ruda (group 400). The deepest horizons are entirely located in the western part of the Upper Silesian Coal Basin and include Siodło (group 500), Poręba (group 600), and Jaklowiec (group 700). Different types of coal, from power coal to coking coal, exist in coal seams. Power coal occurs in the eastern and central areas, while in the west the degree of coalification increases. The thickness of the individual horizons also increases westwards (Kotas 1987; Osika 1970).

\section{The adopted research methodology}

The outcome of the study was the determination of total mercury content in selected Polish coal deposits mined in the Upper Silesian Coal Basin. The examined seams represented different lithostratigraphic members. A variability analysis of the total mercury content in the selected seams of the Krakow sandstone series was conducted in the Libiąż and 
Łaziska horizons; in the mudstone series the Orzesze horizons; and in the Upper Silesia sandstone series the Ruda and Siodło horizons as well as the Poręba and Jaklowiec horizons. Nearly 100 coal samples were analysed for total mercury content. From 1 to 6 samples were collected from each seam. Coal samples from a total of 35 seams in 17 mines (Table 1 and 2) were studied. Coal samples were collected directly from the seams and did not undergo the enrichment process. Raw sample coals were reduced to laboratory samples and subjected to grinding and mixing during the preparation of test samples (particle size $<0.2 \mathrm{~mm}$ ).

Total mercury was determined in all the samples. For each sample two measurements were made, and the value analysed was the arithmetic mean of the measurements. Employed was a modification of the classical AAS method, which allows measurement of threshold values (in nanograms) of mercury in solid and liquid samples of different origin. The advantage of the applied methodology is that is it possible to eliminate the sample pretreatment step. Sample mineralisation takes place within the analyser, immediately prior to

TABLE 2

The results of mercury content measurements in supplied coal samples from individual lithostratigraphic members of the eastern, central, and western part of the Upper Silesian Coal Basin own research of authors

TABELA 2

Wyniki pomiarów zawartości rtęci w dostarczonych próbkach węgli z poszczególnych ogniw litostratygraficznych wschodniej, centralnej i zachodniej części GZW badania własne autorów

\begin{tabular}{|c|c|c|c|c|c|c|}
\hline \multirow{2}{*}{\multicolumn{2}{|c|}{$\begin{array}{l}\text { Llithostratigraphic } \\
\text { members }\end{array}$}} & \multirow{2}{*}{ Seams } & \multicolumn{3}{|c|}{$\begin{array}{l}\mathrm{Hg} \text { total content }[\mathrm{mg} / \mathrm{kg}] \\
\quad \text { (in the air-dry state) }\end{array}$} & \multirow{2}{*}{$\begin{array}{l}\text { No. of } \\
\text { samples }\end{array}$} \\
\hline & & & average & $\min$. & $\max$ & \\
\hline $\begin{array}{l}\text { Libiąż } \\
\text { horizon }\end{array}$ & \multirow{2}{*}{$\begin{array}{l}\text { Krakow } \\
\text { sandstone } \\
\text { series }\end{array}$} & group $\mathbf{1 0 0}(118,119)$ & 0.0313 & 0.0058 & 0.0516 & 9 \\
\hline $\begin{array}{l}\text { Laziska } \\
\text { horizon }\end{array}$ & & $\begin{array}{c}\text { group } 200 \\
(203,205,206,207,209)\end{array}$ & 0.0817 & 0.0029 & 0.2987 & 26 \\
\hline $\begin{array}{l}\text { Orzesze } \\
\text { horizon }\end{array}$ & $\begin{array}{l}\text { Mudstone } \\
\text { series }\end{array}$ & $\begin{array}{c}\text { group } 300(304,308,324,325, \\
352,364)\end{array}$ & 0.1012 & 0.0377 & 0.1652 & 10 \\
\hline $\begin{array}{c}\text { Ruda } \\
\text { horizon }\end{array}$ & \multirow{2}{*}{$\begin{array}{c}\text { Upper } \\
\text { Silesian } \\
\text { sandstone } \\
\text { series }\end{array}$} & $\begin{array}{c}\text { group } 400(401,402,404,405, \\
407,408,410,411,416,418)\end{array}$ & 0.0935 & 0.0168 & 0.3026 & 22 \\
\hline $\begin{array}{l}\text { Siodło } \\
\text { horizon }\end{array}$ & & $\begin{array}{c}\text { group } 500(501,502,503,504 \\
506,507,510)\end{array}$ & 0.0787 & 0.0076 & 0.2087 & 21 \\
\hline $\begin{array}{l}\text { Poręba } \\
\text { horizon }\end{array}$ & - & group 600 (615) & 0.0457 & 0.0457 & 0.0457 & 1 \\
\hline $\begin{array}{l}\text { Jaklowiec } \\
\text { horizon }\end{array}$ & - & group $700(703,707,712,713)$ & 0.0591 & 0.0109 & 0.1970 & 8 \\
\hline
\end{tabular}

Moisture samples in air-dry state: generally $1.3-4.7 \%$. 
the detection process. This minimizes losses of mercury which always occur in conventional analytical methods. To conduct the study AMA-254, a dedicated atomic absorption spectrometer by Altec was used. The study method applied corresponding analytical techniques recommended in the work of A. Okońska et al. (2013) to determine mercury content in coal samples.

\section{Analysis of study results on mercury content in coal seams}

Total mercury content measured in all the samples of coal ranged from 0.0029 $-0.3026 \mathrm{mg} / \mathrm{kg}$. In the range limited by the upper and lower quartiles ( 25 and $75 \%$ ), mercury content ranged from $0.0316-0.0989 \mathrm{mg} / \mathrm{kg}$, with an average value of $0.0567 \mathrm{mg} / \mathrm{kg}$. The obtained results were comparable with values reported in the work of A. Michalska and B. Białecka (2012) (Table 3).

The measured mercury content in all the coal samples collected from the seams in the Upper Silesian Coal Basin is listed in Figure 3. The total mercury content was provided in the air-dry (analytical) state of the samples. The moisture content in the carbon samples in the analytical state was not large, generally ranging from 1.3 to $4.7 \%$, and only in individual

TABLE 3

Averaged mercury content in coal, including the results of the conducted research

TABELA 3

Uśredniona zawartość rtęci w węglach kamiennych z uwzględnieniem wyników prowadzonych badań

\begin{tabular}{||l|c|c||}
\hline \multicolumn{1}{|c|}{ Origin of coal } & $\begin{array}{c}\text { Range of total } \\
\text { mercury content } \\
{[\mathrm{mg} / \mathrm{kg}]}\end{array}$ & $\begin{array}{c}\text { Averaged total } \\
\text { mercury content } \\
{[\mathrm{mg} / \mathrm{kg}]}\end{array}$ \\
\hline \hline Coal from USCB (averaged according to research authors) & $0.003-0.303$ & 0.074 \\
\hline $\begin{array}{l}\text { Coal from USCB } \\
\text { (according to research by I. Bojakowska, G. Sokołowska 2001) }\end{array}$ & $0.001-0.758$ & 0.060 \\
\hline $\begin{array}{l}\text { Power coal from USCB region (according to research by } \\
\text { A. Okońska et al. 2013) }\end{array}$ & $0.070-0.276$ & 0.138 \\
\hline $\begin{array}{l}\text { Coal from USCB } \\
\text { (according to research by T. Chmielniak et al. 2012) }\end{array}$ & $0.019-0.168$ & 0.073 \\
\hline $\begin{array}{l}\text { Coal from Poland (according to research by } \\
\text { I. Bojakowska, G. Sokołowska 2001) }\end{array}$ & $0.001-0.967$ & 0.085 \\
\hline $\begin{array}{l}\text { Coal from USCB in range limited by lower and upper quartiles } \\
\text { (according to research authors) }\end{array}$ & $0.03-0.10$ & 0.057 \\
\hline $\begin{array}{l}\text { Raw coal from USCB region (average from mines within range } \\
\text { limited by lower and upper quartilesaccording to research by } \\
\text { A. Michalska i B. Białecka 2012) }\end{array}$ & $0.07-0.12$ & - \\
\hline
\end{tabular}




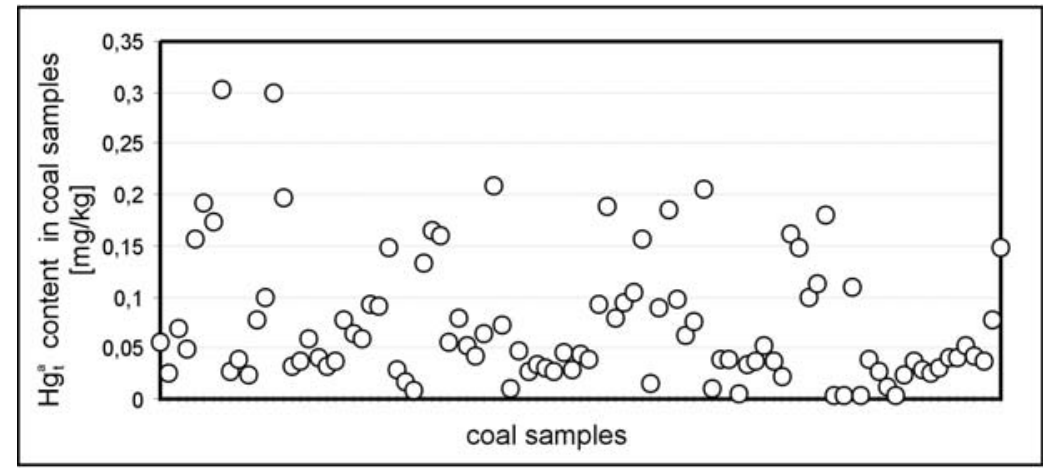

Fig. 3. Listed measured mercury content in all coal samples collected from individual seams in the Upper Silesian Coal Basin - own research of authors

Rys. 3. Zbiorcze zestawienie pomierzonych zawartości rtęci we wszystkich próbkach pobranych z poszczególnych pokładów na obszarze GZW - badania własne autorów

cases reaching $10 \%$. Such hygroscopic moisture values have been found in other studies (e.g. Baic 2013).

In individual mined regions, the total mercury content in the samples from all the seams of a particular mine (Table 1) was averaged. Mercury content in 17 coal mines averaged $0.0852 \mathrm{mg} / \mathrm{kg}$. The highest values were obtained for mine No. 3 (seam in Łaziska horizons) and mine No. 7 (seam in Orzesze horizons), where the averaged total mercury content in the samples was $0.15-0.16 \mathrm{mg} / \mathrm{kg}$. The lowest average total mercury content of $0.03-0.04 \mathrm{mg} / \mathrm{kg}$ was reported in coal samples from mine No. 10 (seams in Siodło and Poręba horizons), mine No. 1 (seams in Orzesze, Ruda, and Siodło horizons), and No. 17 (seams in Łaziska and Orzesze horizons). No relationship has been observed between the average mercury content in coal from different mines and the lithostratigraphic location of the seams.

Taking into account the fact that the coal samples came from different horizons and seams (Table 2, Figure 4), the highest mercury content of up to $0.3 \mathrm{mg} / \mathrm{kg}$ was found in samples from the seams of group 200 (Laziska horizon) and group 400 (Ruda horizon). The lowest mercury content of only $0.003 \mathrm{mg} / \mathrm{kg}$ was measured in samples from the seams of group 200 (Table 2). After the measured values from all samples within a particular seam were averaged, it can be said that the total mercury content in the analysed seams ranged between $0.031-0.101 \mathrm{mg} / \mathrm{kg}$. The highest average values were observed in the group of seams from the Orzesze horizon, and the lowest in the group of seams from the Libiąz horizons. It should be noted that in two samples, high point concentrations of mercury in excess of $2 \mathrm{mg} / \mathrm{kg}$ were reported. In the analysis of the results and the estimation of average values however, this value was omitted. It may be assumed that such high levels of mercury are not typical for the seam and may only be associated with localized carbon mineralisation. The most likely causes of a local increase in mercury content in coal are trace inclusions of mercury minerals (e.g. cinnabar) observed in the Polish coal deposits, especially in the Wałbrzych area (Bojakowska, Sokołowska 2001). 


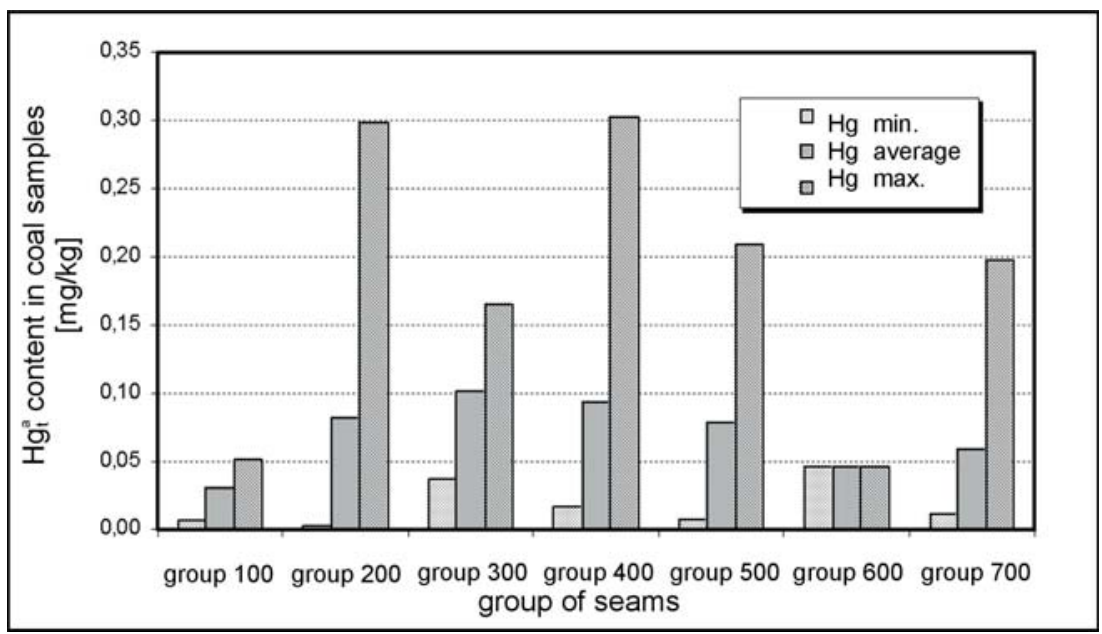

Fig. 4. The averaged results of mercury content measurements in available coal samples from individual groups of seams - own research of authors

Rys. 4. Uśrednione wyniki pomiarów zawartości rtęci w dostarczonych próbkach węgli dla poszczególnych grup pokładów - badania własne autorów

An analysis of the results leads to the conclusion that varying total mercury content in coal may be observed in the Upper Silesian Coal Basin coal deposits. However, a limited number of observations in individual seams does not allow any conclusions about the relationship between the content of this element in the examined material and different lithostratigraphic members. Nevertheless, it does supplement the scope of knowledge concerning the content of mercury in coals from the USCB seams. A significant divergence of the values depends rather on the number of samples collected within an analysed horizon of a particular group (Table 2). Similar conclusions were widely described in the work of Z. Kokesz (2010) with regard to sulphur.

The average mercury content in the samples from the mined seams analysed in this study amounted to $0.0739 \mathrm{mg} / \mathrm{kg}$. There was no clear differentiation in mercury content between the eastern and the central-western mining regions. In the eastern part (mining and sampling area - mines Nos. 16 and 17), the measured total mercury content ranged from 0.0029 to $0.2987 \mathrm{mg} / \mathrm{kg}$, with an average of $0.0512 \mathrm{mg} / \mathrm{kg}$. In the central-western part (mining and sampling area - mines Nos. 1 to 15 ), the total mercury content ranged from 0.0076 to $0.3026 \mathrm{mg} / \mathrm{kg}$, and averaged $0.0899 \mathrm{mg} / \mathrm{kg}$. The average mercury content in the sampled seams was much lower than in the case of power coal described by A. Okońska et al. (2013) and was at a level comparable to that of the data provided in the papers by other authors (Bojakowska, Sokołowska 2001; Chmielniak et al. 2012) listed in Table 3. The research methodology adopted in the present study was the same as that prescribed and used in the works of A. Okońska et al. (2013), T. Chmielniak et al. (2012), and A. Michalska and B. Białecka (2012). 


\section{Summary and conclusions}

This study examined the mercury content of nearly 100 samples from the coal seams of the Upper Silesian Coal Basin. The analysis of mercury content indicated its presence in all of the investigated material. Total mercury content measured in all the coal samples ranged from 0.0029 to $0.3026 \mathrm{mg} / \mathrm{kg}$, and averaged $0.0739 \mathrm{mg} / \mathrm{kg}$. In the range limited by the lower and upper quartiles, mercury content ranged between 0.0316 and $0.0989 \mathrm{mg} / \mathrm{kg}$. Often in individual samples from genetically similar deposits, mercury content in coal varied by as many as several orders of magnitude, as observed primarily within the Łaziska and Ruda horizons.

An analysis of the obtained results leads to the conclusion that in Polish coal deposits, mercury content is comparable to the levels described in deposits worldwide. Mercury content in the coal from the analysed horizons varied considerably and was mostly consistent with the data provided in existing Polish documentation or was much lower.

The results of this analysis have broadened the scope of knowledge concerning mercury content in coal from the USCB seams, and its variability study has a clear cognitive aspect. It should be noted, however, that a limited number of samples - and thus measurements in individual seams does not allow for any decisive conclusions. The results of this study do not make it possible to relate total mercury content in selected seams with its lithostratigraphic position.

The authors would like to thank the mines for providing the coal samples used in this study

\section{REFERENCES}

B a i c I., 2013 - Analiza parametrów chemicznych, fizycznych i energetycznych depozytów mułów węglowych zinwentaryzowanych na terenie woj. śląskiego (Analysis of the Chemical, Physical and Energetic Parameters of Coal Sludge Deposits Inventoried in the Silesian Province). Annual Set The Environment Protection (Rocznik Ochrona Środowiska), Middle Pomeranian Society of the Environment Protection, Vol. 15, pp. 1525-1548.

B archański B., 2010 - A jednak węgiel to teraźniejszość i przyszłość energetyki (And yet coal is the present and the future of power engineering). Energy Policy Journal (Polityka Energetyczna), IGSMiE PAN, Vol. 13, issue 2, pp. 11-27.

B las chke W., 2005 - Węgiel kamienny energetyczny - jego przyszłość w kraju i na świecie (Future of Hard Coal in the Use in Power Industry in Poland and in the Word). Mineral Resources Management (Gospodarka Surowcami Mineralnymi), IGSMiE PAN, Vol. 21 - special issue 1, pp.71-82.

Bojakowska I., Sokołowska G., 2001 - Rtęć w kopalniach wydobywanych w Polsce jako potencjalne źródło zanieczyszczenia środowiska (Mercury in mineral raw materials exploited in Poland as potential sources of environmental pollution). Biuletyn Państwowego Instytutu Geologicznego 394, pp. 5-54.

Bojarska K., 2006 - Concentration of mercury in Polish hard coals. MEC3 Third International Expert' sworkshop, Katowice June 5-7 2006.

Chmielniak et al. 2012 - ChmielniakT., Misztal E., Kmieć M., Mazurek I., 2012 - Rtęć w węglach stosowanych w polskim sektorze energetycznym (Mercury content in Polish coals used in power sektor). Wydawnictwo Górnicze, Karbo nr 3, pp. 154-163. 
EURELECTRIC Comments on the Consultation Document Development of the EU Mercury Strategy; 2004; http://ec.europa.eu/

Gawłowski et al. 2010 - Gawłowski S., Lisowska-Gawłowska R., Piecuch T., 2010 - Uwarunkowania i prognoza bezpieczeństwa energetycznego Polski na lata 2010-2110 (Conditions and Forecast of Poland's Energy Safety for the period 2010-2110). Rocznik Ochrona Środowiska, Middle Pomeranian Society of the Environment Protection, Vol. 12, pp. 127-176.

Głodek A., P a c yna J.M., 2007 - Możliwości redukcji emisji rtęci ze spalania węgla (Potential of reducing mercury emission from the coal combustion processes). Ochrona Powietrza i Problemy Odpadów, Vol. 4, nr 2, pp. 53-63.

Grudziński Z., 2013 - Koszty środowiskowe wynikające z użytkowania węgla kamiennego w energetyce zawodowej (Environmental Costs Resulting from the Use of Coal in the Power Sektor). Rocznik Ochrona Środowiska). Middle Pomeranian Society of the Environment Protection, Vol. 15, pp. 2249-2266.

Klojzy-Karczmarczyk B., Mazurek J., 2007 - Zanieczyszczenie gleby związkami rtęci w zasięgu oddziaływania konwencjonalnej elektrowni na paliwo węglowe (Soil contamination by mercury compounds in influence zone of coal-based power station). Energy Policy Journal (Polityka Energetyczna), IGSMiE PAN, Vol. 10, special issue 2, pp. 593-601.

Kloj zy-Ka r c z marc zy k B., M a zu re k J., 2008 - Badania rtęci w wybranych złożach ropy naftowej regionu karpackiego (Research on mercury content in selected petroleum deposits of Carpathian region (Poland)). Energy Policy Journal (Polityka Energetyczna), IGSMiE PAN, Vol. 11, issue 1, pp. 211-217.

Ko ke s z Z., 2010 - Geostatystyczna analiza zmienności zawartości siarki w wybranych pokładach węgla GZW (Geostatistical analysis of variability of the sulphur content for selected coal seams in Upper Silesian Coal Basin). Mineral Resources Management (Gospodarka Surowcami Mineralnymi), IGSMiE PAN, Vol. 26, issue 3, pp. 95-110.

Kota s A., 1987 - Górnośląskie Zagłębie Węglowe [W:] Budowa geologiczna Polski - złoża surowców mineralnych (Ed. Osika R.); Wydawnictwa Geologiczne, Warszawa.

Leśniewska et al. 2009 - Leśn i e w s k a E., S zy n k ow s k a M.I., P a ryj c za k T., 2009 - Główne źródła rtęci w organizmach ludzi nie narażonych zawodowo (Main Sources of Mercury in Human Organisms not Exposed Professionally). Annual Set The Environment Protection (Rocznik Ochrona Środowiska), Middle Pomeranian Society of the Environment Protection, Vol. 11, pp. 403-419.

L or en z U., 2005 - Skutki spalania węgla kamiennego dla środowiska przyrodniczego i możliwości ich ograniczania (Consequences of hard coal combustion for the environment and methods of their reduction). Materiały Szkoły Eksploatacji Podziemnej - Sympozja i Konferencje nr 64, pp. 97-112.

Lorenz U., Grudziński Z., 2008 - Mercury emission and its content in hard and brown coal. Mineral Resources Management (Gospodarka Surowcami Mineralnymi) Vol. 24, issue 3/1; pp. 271-288.

Michalska A., B iałecka B., 2012 - Zawartość rtęci w węglu i odpadach górniczych (The mercury content in coal and waste from processes of the coal mining). Prace Naukowe GIG - Górnictwo i Środowisko; Nr 3/12, pp. 73-87.

Mokrzycki E., Uliasz-B ocheńczyk A., 2009 - Gospodarka pierwotnymi nośnikami energii w Polsce a ochrona środowiska przyrodniczego (Management of Primary Energy Carriers in Poland Versus Environmental Protection). Annual Set The Environment Protection (Rocznik Ochrona Środowiska), Middle Pomeranian Society of the Environment Protection, Vol. 11, pp. 103-131.

Okońska et al. 2013 - Okońska A., Uruski Ł., Górecki J., Gołaś J., 2013 - Metodyka oznaczania zawartości rtęci całkowitej w węglach energetycznych (Merkury In Coal - Determinationa of Total Marcury in Steam Coals by Cold Vapor Atomic Absorption Spectrometry (CV-AAS). Mineral Resources Management (Gospodarka Surowcami Mineralnymi), IGSMiE PAN, Vol. 29, issue 2, pp. 39-50.

Olku s ki T., 2007 - Porównanie zawartości rtęci w węglach polskich i amerykańskich (Comparision of mercury content in polish and U.S. coals). Energy Policy Journal (Polityka Energetyczna), IGSMiE PAN, Vol. 10, special issue 2, pp. 603-611.

Olkuski T., Stala-Szlugaj K., 2012 - Odbiorcy polskiego węgla energetycznego w eksporcie (Importers of Polish steam coal). Energy Policy Journal (Polityka Energetyczna), IGSMiE PAN, Vol. 15, issue 4, pp. 215-227. 
O sik a R., red., 1970 - Geologia i surowce mineralne Polski. Wydawnictwa Geologiczne, Warszawa.

S moliński A., 2007 - Energetyczne wykorzystanie węgla źródłem emisji rtęci - porównanie zawartości tego pierwiastka w węglach (Coal-based power generation as a mercury emission source - comparison of mercury contents in coals). Ochrona powietrza i problemy odpadów nr 2(238), pp. 45-53.

Szuflicki et al., Ed., 2013 - Szuflicki M., Malon A., Tymiński M., red., 2013 - Bilans zasobów złóż kopalin w Polsce według stanu na 31.XII.2012 r. Państwowy Instytut Geologiczny - Państwowy Instytut Badawczy, Warszawa.

Wichliński et al., 2012 - Wichliński M., Kobyłecki R., Bis Z., 2012 - Przegląd metod ograniczenia emisji rtęci w elektrowniach podczas spalania paliw stałych (Review of methods to limit mercury emissions during combustion of solid fuels in power plants). Energy Policy Journal (Polityka Energetyczna), IGSMiE PAN, Vol. 15, issue 4, pp. 151-160.

W ojn a r K., Wis z J., 2006 - Rtęć w polskiej energetyce (Mercury in Polish power engineering). Energetyka $4(59)$.

BADANIA ZAWARTOŚCI RTECI W WYBRANYCH POKLADACH WEGLA KAMIENNEGO GÓRNOŚLĄSKIEGO ZAGLĘBIA WĘGLOWEGO

\section{Słowa kluczowe}

Górnośląskie Zagłębie Węglowe, węgiel kamienny, pokłady, rtęć całkowita

\section{Streszczenie}

W ostatnich latach struktura zużycia paliw w Polsce zmieniła się w niewielkim stopniu, a paliwa dominujące w gospodarce energetycznej to nadal węgiel kamienny oraz węgiel brunatny. Powszechnie znanym zjawiskiem jest obecność rtęci w węglach. Jej zawartość w próbkach węgla kamiennego pochodzących z różnych złóż światowych kształtuje się najczęściej na poziomie od 0,03 do $0,3 \mathrm{mg} / \mathrm{kg}$, przy czym zawartość rtęci w poszczególnych pokładach jest zróżnicowana.

W pracy przedstawiono wyniki badań zawartości rtęci w blisko 100 próbkach węgla kamiennego pobranych z pokładów Górnośląskiego Zagłębia Węglowego. Wytypowane do badań pokłady reprezentują różne ogniwa litostratygraficzne (warstwy libiąskie, łaziskie, orzeskie, rudzkie, siodłowe oraz porębskie i jaklowieckie). Przebadano próbki węgla kamiennego łącznie z 35 pokładów w 17 kopalniach. Wykonane analizy zawartości rtęci wykazały jej zróżnicowaną obecność w całym badanym materiale. Średnia zawartość rtęci w opróbowanych pokładach kształtuje się na poziomie porównywalnym z danymi podawanymi w literaturze lub jest zdecydowanie niższa.

Zawartość rtęci całkowitej, pomierzona we wszystkich próbkach węgla kamiennego mieści się w granicach od 0,0029 do $0,3026 \mathrm{mg} / \mathrm{kg}$, natomiast jej wartość uśredniona kształtuje się na poziomie $0,0739 \mathrm{mg} / \mathrm{kg}$. Często, w pojedynczych próbkach pochodzących z podobnych genetycznie złóż, zawartości rtęci w węglu różnią się nawet o kilka rzędów wielkości, co obserwowane jest przede wszystkim w obrębie warstw łaziskich oraz rudzkich. Brak jest wyraźnego zróżnicowania zawartości rtęci w podziale na część wschodnią eksploatacji oraz część centralną i zachodnią. W odniesieniu do próbek pobranych w każdej z kopalń, średnia zawartość rtęci mieści się w granicach od 0,0331 do $0,1589 \mathrm{mg} / \mathrm{kg}$. Nie obserwuje się zależności pomiędzy uśrednioną zawartością rtęci w węglach z poszczególnych kopalń a przynależnością litostratygraficzną eksploatowanych pokładów. Całkowitą zawartość rtęci podano w stanie powietrzno-suchym (analitycznym) analizowanych próbek.

Ze względu na małą liczbę próbek pobranych z eksploatowanych pokładów oraz stwierdzony szeroki zakres zmienności, przeprowadzone badania nie pozwalają na powiązanie zawartości rtęci całkowitej w wybranych pokładach z ich pozycją litostratygraficzną. Wyniki pracy pozwoliły jednak na zdecydowane rozszerzenie wiedzy dotyczącej zawartości rtęci w węglach z pokładów GZW, a badanie jej zmienności wykazuje wyraźny aspekt poznawczy. 
106

STUDIES OF MERCURY CONTENT IN SELECTED COAL SEAMS OF THE UPPER SILESIAN COAL BASIN

$$
\text { Key words }
$$

Upper Silesian Coal Basin, coal, seams, total mercury

\section{Abstract}

The structure of fuel consumption in Poland has changed very little in recent years, and coal and lignite are still the dominant fuels in the energy sector. The presence of mercury in coal is a common phenomenon. Its content in coal samples from various deposits from around the world typically ranges from 0.03 to $0.3 \mathrm{mg} / \mathrm{kg}$; however, the amount of mercury in each seam varies.

This paper presents the results of mercury content studies of nearly 100 samples collected from the coal seams of the Upper Silesian Coal Basin. The seams selected for examination represent different lithostratigraphic members (Libiąż, Łaziska, Orzesze, Ruda, Siodło, Poręba, and Jaklowiec horizons). Coal samples from a total of 35 seams in 17 mines were studied. The mercury content analysis indicated that the amount of this element varied in the examined material. The average mercury content in the sampled seams was comparable with the data provided in exiting documentation or was much lower.

The total mercury content measured in all the coal samples ranged from 0.0029 to $0.3026 \mathrm{mg} / \mathrm{kg}$, and averaged $0.0739 \mathrm{mg} / \mathrm{kg}$. Frequently, in individual samples from genetically similar deposits, mercury content in coal varied by several orders of magnitude, which was evident primarily within the Łaziska and Ruda horizons. There is no clear differentiation in mercury content between the eastern and the central-western mining regions. In the samples collected in all the mines, the average mercury content ranged from 0.0331 to $0.1589 \mathrm{mg} / \mathrm{kg}$. There was no relationship between the average mercury content in coal from different mines and the lithostratigraphic origin of the mined seams. The total mercury content was provided in the air-dry (analytical) state of the samples.

Due to the small number of samples collected from the mined seams and the wide range of variability discovered, the conducted studies do not allow for the relation of total mercury content in selected seams to their lithostratigraphic position. These results, however, have significantly extended the scope of knowledge about mercury content in coal from the USCB seams. Moreover, the study of coal content variability has a distinct cognitive aspect. 